\title{
Pursuing Legal Research
}

\author{
Synne Scether Mchle*
}

\section{$1 \quad$ Introduction $^{1}$}

Legal research starts with an idea. Triggering a researcher's interest, curiosity or imagination begins the research process aimed at formulating a clear research question, finding a fruitful approach ${ }^{2}$ and establishing rigorous answers. Throughout this process, legal research involves methodological assessments. Some concern choosing and delineating the field of inquiry. Awareness of the need for methodological assessments when delineating a field of inquiry is called for in various research areas such as doctrinal research (Vranken 2011, p. 117 and p. 119), international law (d'Aspremont 2015, p. 177-198) and legal theory (Donnelly 2007, p. 78). A vital component of such a methodological perspective is to establish pursuit-worthy lines of inquiry (see generally Šešelja, Kosolosky \& Straßer 2012; Šešelja \& Straßer 2014; Whitt 1990; 1992). Legal researchers establish pursuit-worthy lines of inquiry by constructing and exploring promising lines of inquiry in search of fruitful contributions to improved understanding of law. Simultaneously, researchers remain open-minded as to whether such inquiry ultimately results in the best approach to answering the research question and to contributing to improved understanding of law (see generally Šešelja, Kosolosky \& Straßer 2012; Šešelja \& Straßer 2014; Whitt 1990; 1992).

Two aspects of how researchers establish pursuit-worthy lines of inquiry are highlighted. The first aspect is to construct promising lines of inquiry. The second aspect is to clarify provisionally the potential of various promising lines of inquiry. Discourse with fellow researchers is essential to clarifying and calibrating such potential. Highlighting such aspects increases awareness of how legal researchers assess lines of inquiry and choose pursuit-worthy ones. Awareness of these methodological assessments is vital to contemporary discourse about legal methodology, where there is considerable debate on what constitutes - for

* Dr. Juris Synne Sæther Mæhle, Associate Professor, Faculty of Law, University of Bergen, Norway. E-mail: synne.mahle@uib.no.

1 Helpful input has been received from Amalia Amaya, Jørn Jacobsen, Knut Martin Tande and two anonymous reviewers. The article results from a research project at the Faculty of Law, University of Bergen, Norway about methodology in legal research in interdisciplinary projects ['Rettsvitenskapelig forskningsmetodikk i tverrvitenskapelige prosjekt'], funded in part by the The Research Council of Norway.

2 'Approaches' is used widely to encompass ways of conducting research, accounts of their appropriateness and methodological awareness of both the possibilities and limitations of various approaches (see van Gestel, Micklitz \& Maduro 2012, p. 2, 5 and 20). 
instance - fruitful, valuable and interesting legal research (see e.g., Dickson 2017; Enoch 2015). Such awareness is particularly important when developing and articulating interest in the fruitful diversity - arguably even the continuity (Giudice 2015, p. 213) - of complementary and conflicting approaches to understanding law.

To identify and explain why establishing pursuit-worthy lines of inquiry is integral to legal research, section two briefly sets improved understanding of law as a general aim for legal research and adjusts it to suit the perspective of researchers interested in exploring the potential for gaining insight into law by pursuing certain lines of inquiry. ${ }^{3}$ Section three indicates current debate about pursuit as integral to legal research. Sections four and five outline the two mentioned aspects of how legal researchers assess which lines of inquiry are worth pursuing. Section six maps avenues for future research and offers concluding remarks.

\section{Aspiring for Improved Understanding of Law}

Legal research aspires for improved understanding of law (Giudice 2015, p. 229; Halpin 2009, p. 145), ${ }^{4}$ an understanding that is richer, deeper or more comprehensive. Concerning what represents improved understanding, most legal researchers share some overarching research ideals, or 'generally accepted quality criteria for legal research' (Vranken 2011, p. 120). These ideals simultaneously 'guide and constrain' (Whitt 1990, p. 472) what constitutes improved understanding. Such research ideals include 'originality (innovation), rigour, significance, thoroughness and exploring boundaries' (p. 120 footnote omitted). ${ }^{5}$

Most legal researchers generally agree on what these ideals entail. For example, even though the issue of originality is controversial (Siems 2008, p. 148), most agree that innovative legal researchers 'make connections that others do not see, or shed new light from an unexpected angle on an existing problem' (Vranken 2011, p. 112). For instance, inquiring into a 'principle of humanity' in international humanitarian law is innovative when it produces 'greater clarity concerning the possible emergence, existence, function and significance' of such a principle (Larsen, Cooper \& Nystuen 2013, p. 1).

Still, what constitutes improved understanding is debated by legal scholars. Several factors cause controversy. One is that 'improved understanding of law' sets an abstract aim, which can be specified differently. Does clarity imply simplicity, for instance, and if so, which kind of simplicity (Aroney 2013, p. 9-10)? Sometimes complex concepts are arguably most clarifying (Alexy 2002, p. 43). In addition, diverse ways of achieving better understanding can be prioritized differently, depending on the research question (see e.g., Aroney 2013, p. 10). Another cause of controversy is the manifold kinds of legal research, such as legal

3 Such adjustment is inspired by Šešelja and Straßer 2014, see e.g., p. 3117.

4 Other general aims and their interrelations are not scrutinized.

5 Additional criteria may adhere to specific research methods. 
doctrinal research, general jurisprudence and normative jurisprudence, with sometimes differing perspectives on what constitutes improved understanding. How the use-value of legal research for legal practice correlates with the general aim of achieving better understanding is often of central concern. ${ }^{6}$ Additionally, improving understanding is not a binary endeavour, but one of degrees.

In short, certainty in this endeavour is elusive; indeed, there are 'different normative points of view on what it means to improve or develop the law' (de Been, Taekema \& van Klink 2016, p. 17). What both suggests nascent understanding and ultimately constitutes improved understanding probably varies depending on the theoretical perspective or framework (Taekema \& van der Burg 2014, p. 130), or according to the concept(s) of systematicity - as in science generally (Hoyningen-Huene 2013, p. 28). One way of achieving systematicity is to investigate the consistency and coherence of a legal system of rules. Viewed in this theoretical perspective, improved understanding can be produced when researchers build or enhance systems of rules, such as by clarifying newly formed rules, elucidating additions to existing rules and uncovering interconnections between rules. However, such 'systematicity of rules', as phrased by d'Aspremont (2017, p. 367), is not a static, ready-made theoretical perspective. Delineating a system of rules involves methodological assessments and choices made by the researcher (d'Aspremont 2017, p. 370; Vranken 2011, p. 114-118). Additionally, such systematicity of rules is not the only achievable form of systematicity in legal research (Vranken 2011, p. 118). Systematicity 'of legal arguments' might be another (d'Aspremont 2017, p. 367). Differing forms of systematicity also probably overlap (d'Aspremont 2017, p. 369) - as they do in science generally (Hoyningen-Huene 2013, p. 28). Consequently, deciding what constitutes improved understanding depends on legal researchers' methodological assessments and subsequent choices.

Such methodological assessments and choices are most apparent when discussing what constitutes the best approach to researching law. Presently, legal scholars extensively debate several methodological questions concerning why particular research methods or approaches generally should be considered the preferred route to improved understanding. Why employ constructive conceptual explanation, for instance (Giudice 2015)? Why employ an approach to international law with empirical components entitled 'European New Legal Realism' (Holtermann \& Madsen 2015)? Some even claim the superiority of a particular approach. ${ }^{7}$

Equally important is that researchers choose how to pursue legal research in light of methodological assessments of what constitutes improved understanding. Such assessments of what is pursuit worthy in legal research differ slightly from assessments of what ultimately constitutes the best approach (see generally Šešelja, Kosolosky \& Straßer 2012; Šešelja \& Straßer 2014; Whitt 1990; 1992).

6 Questions regarding the usefulness of legal research for legal practice or as background for lawmaking will not be scrutinized.

7 Claims of one specific method as 'the correct method which all theories of law must adopt' (Giudice 2015, p. 164) are not scrutinized here. 
Both assessment modalities aspire for improved understanding, but, essentially, assessments of what is pursuit worthy are explorative and tentative. They are explorative because researchers attempt to develop important ${ }^{8}$ (see e.g., Donnelly 2007, p. 82; Šešelja \& Straßer 2014 p. 3123-3137) insight using both traversed lines of inquiry and newly discovered theoretical landscapes while remaining open-minded as to whether such inquiry ultimately results in the best approach to answering the research question and to contributing to improved understanding of law (regarding open-mindedness generally, see e.g., Whitt 1990, p. 476). In pursuit of improved understanding, researchers will ask: How and why will exploring this subject matter by using particular lines of inquiry contribute? (Regarding prospectiveness generally, see Šešelja \& Straßer 2014, p. 3117; Whitt 1992, p. 616.) Will the research contribute by developing law at a high level of generality, for instance? Or does the research target comparatively specific insight (Aroney 2013, p. 10 and p. 24; Donnelly 2007, p. 82)? Will the research be harmonious with neighbouring research, or will it contrast with the present understanding of law? In short, assessing how to pursue legal research is to explore the potential of promising lines of inquiry (regarding promise generally, see Šešelja \& Straßer 2014, p. 3115; Whitt 1990, p. 471; 1992, p. 616). ${ }^{9}$ Assessments of what is pursuit worthy in legal research are also tentative because the provisional potential must be clarified and further scrutinized - above all, in discourse with fellow legal researchers. I will return to this aspect of assessing pursuit-worthy lines of inquiry in section five. First, a few words on how pursuit as exploring the potential of diverse approaches is currently debated in legal scholarship.

\section{Pursuit Worthy?}

The notion of pursuit as integral to legal research is presently surfacing in legal scholarship. Several legal researchers in contemporary debate about legal methodology believe that it is important to seek and distinguish the potential in different approaches to understanding law. For example, cooperation is encouraged between legal philosophy, legal sociology and doctrinal legal scholarship in order to 'gain a full understanding of law in all its facets' (Taekema \& van der Burg 2014, p. 142). Another example is to explore the merits of different senses of explanatory priorities and methodological approaches (Dickson 2013, p. 364). A third example is to clarify the relative explanatory powers of legal theories in 'paired qualities' (Aroney 2013, p. 2) to enable a 'rigorous pursuit of explanatory power' (p. 3 and p. 24). A fourth example is Giudice's fronting of the constructive conceptual explanation as fruitful in exploring the 'value of seeking to understand

8 Whether some aspects must necessarily be included, and if so in what sense, are well-known questions in legal philosophy, but this discursive strand will not be scrutinized.

9 Possible differences between evaluating the intrinsic potential of one line of inquiry and comparatively evaluating alternatives (see Šešelja, Kosolosky \& Straßer 2012, p. 4-5) are not scrutinized. 
and pursue relations - both complementary and conflicting - between diverse approaches to understanding law' (2015, p. 213). Finally, a fifth example is Halpin's elaboration of the 'initial elucidatory expository', 'secondary expository', 'exploratory explanatory' and 'normatively exploratory' roles of conceptual analysis (2009, p. 149-150) and methodology (p. 154).

These examples both highlight and exhibit that researchers often 'do something other than accept or reject' (Whitt 1990, p. 467, see also Šešelja \& Straßer 2014, p. 3121; Whitt 1992, p. 632) possible approaches to law - we pursue different approaches to understanding law in order to explore their potential when researching a field of inquiry.

Worth highlighting, to clarify the notion of pursuit as integral to legal research, is a development in discourse about research generally. Generally, the 'notion of the context of pursuit resulted from the discussion on the traditional distinction between the context of discovery and the context of justification' (Šešelja \& Straßer 2014, p. 3113, see also p. 3120-3121; Šešelja, Kosolosky \& Straßer 2012, p. 1). ${ }^{10}$ The term 'context of pursuit' is usually attributed to Laudan (1977). Recently, Šešelja and Straßer have highlighted that awareness of the context of pursuit in research is important:

[W] hat we are concerned with in the context of pursuit is not the question as to whether a theory is acceptable, but as to whether there are good epistemic reasons for its further pursuit. We will say that a theory is epistemically worthy of pursuit to the extent that it can be shown to have a promising potential for contributing to those epistemic goals that determine theory acceptance, as well as to the value of robustness of scientific knowledge (2014, p. 3114-3115, italics in original).

Šešelja and Straßer offer 'potential coherence' (p. 3121) as crucial to assess the potential of 'explanatory theoretical frameworks' (p. 3115). They elaborate four 'prospective values' (p. 3117) for the evaluation of 'pursuit worthiness': 'Potential Explanatory Power', 'Potential Inferential Density', 'Potential Consistency' and 'Programmatic character' (Šešelja \& Straßer 2014, p. 3123). ${ }^{11}$ These prospective values, as I understand Šešelja and Straßer, both guide and constrain (see p. 3133) the pursuit of robust ${ }^{12}$ scientific knowledge. Worth mentioning is that Šešelja and Straßer 'focus ... on the assessment of pursuit worthiness of young theories' (p. 3115) and that they elaborate 'initial' and 'successive' assessments of pursuit

10 See p. 3114 for their overview of literature where the question 'whether a given scientific idea is worthy of pursuit' (p. 3113-3114) is found as 'evaluation under different names' (p. 3114). See also Šešelja, Kosolosky and Straßer (2012, p. 1-2).

11 'Non-epistemic factors' can impact assessments of pursuit worthiness (Šešelja \& Straßer 2014, p. 3115 and p. 3135). See also Šešelja, Kosolosky and Straßer (2012, p. 9-12); Whitt (1990, p. 470).

12 'Robust' is explained as being 'able to maintain its key functions of explaining and helping us to understand the world, by means of avoiding and, if necessary, by overcoming scientific crisis' (p. 3112). 
worthiness (p. 3123). Further interdisciplinary research is needed to transpose these prospective values into discourse about legal research, for instance, because coherence in law embodies a well-known complex relation to consistency and possibly entails a crucial link to legal principles (Amaya 2015, p. 472). Still, mindful of this reservation, the term 'pursuit worthiness' can be used when discussing how legal researchers construct and explore promising lines of inquiry.

Before returning to how legal researchers pursue such potential for insight, it is worth mentioning that the term 'context of pursuit' is not widespread in legal scholarship. An exception is found in Amalia Amaya's recent work. She explicates a context of pursuit as 'an intermediate stage that is exceedingly important, to wit, a "context of pursuit", in which working hypotheses are subjected to a preliminary assessment and developed in further detail' (Amaya 2015, p. 505, footnote omitted). She employs it to argue that an integral part of legal decision-making is to make 'a reasonable pool of alternatives ... the best that they can be, in order to ensure a fair comparison of their relative degree of coherence' (Amaya 2015, p. 508, see also p. 509-515). Although she focuses on legal decision-making (see e.g., main tenet on p. 531), her model does not preclude reasoning in legal research, in my opinion. Important elements in her model are derived from the philosophy of science. For example, she presents the context of pursuit with reference to Laudan (Amaya 2015, p. 505, note 78). Other important elements are also associated with theories encompassing research. Central features of her notion of coherence, such as 'constraint-satisfaction', are modelled after Thagard's notion, which concerns several domains (Amaya 2015, see e.g., p. 195-244, p. 478 and p. 487-503). Contextually variant constraints are also associated with Peczenik's coherence theory of law (Amaya 2015, p. 23-37, p. 531 and p. 547), which encompasses research (see e.g., Peczenik 2009, p. 198). Generally, Amaya's model has 'building blocks' (p. 477) from a broad interdisciplinary background, not limited to theories of legal decision-making. ${ }^{13}$ In this view, Amaya's model does not preclude reasoning in legal research, although she focuses on decision-making.

Still, legal research and decision-making differ, and their distinguishing properties are significant. Due attention must be given to contextually variant constraints (Amaya 2015, see e.g., p. 478-479, p. 487-503 and p. 525-531), such as institutional structures for legal decision-making, different time constraints and distinguishing argumentative roles for authoritative aspects such as precedents and a constitutional framework. Such differencing factors are central to Amaya's model (see e.g., p. 487-503, p. 525-531 and p. 547). Consequently, more research is required to fully establish whether Amaya's coherence theory of legal reasoning, including the idea of structural commonalities in coherence-based reasoning (see e.g., p. 471, footnote 1, see also p. 544-551) and accompanying constraints that vary with context (see e.g., p. 487-503, p. 525-531 and p. 547), may accommodate reasoning in legal research.

In summary, the idea that legal researchers pursue the potential of relevant, different approaches is currently part of several discursive fronts. So how do 
researchers explore the potential of diverse promising lines of inquiry into law? In section four I argue that researchers pursue legal research by constructing promising lines of inquiry into a research field. Subsequently, in section five, I highlight that clarifying the potential of such a field of inquiry in discourse with fellow legal scholars is integral to researchers' determination of what is worthy of pursuit.

\section{Constructing Promising Lines of Inquiry}

How do legal researchers form a pursuit-worthy field of inquiry? Of central concern here is that assessments of pursuit worthiness differ from discerning merely possible, albeit fascinating lines of inquiry capable of illuminating a research question. In legal research it is not necessarily easy to identify where generating background knowledge about the field of inquiry ends and pursuing promising insight begins. Naturally, legal research requires some initial background knowledge of the field of inquiry (see e.g., Donnelly 2007, p. 78; Giudice 2015, p. 75-76). Initially, developing such knowledge involves mapping the field of inquiry to discern, at least provisionally, the proper research topic, to explicate the main research question and to find possible lines of further investigation (Taekema \& van der Burg 2014, p. 142). Arguing that 'it is possible to identify the subject matter prior to working through (competing) approaches' (Halpin 2009, p. 153 italics in original) highlights such an initial phase in legal research.

However, delineating a legal field of inquiry is not discovery in the sense of simply observing law as a distant, fully discernible object, nor is it merely identifying possible lines of inquiry. Systems of rules, for instance, are "not "out there" and ready to be discovered' (d'Aspremont 2017, p. 370). Additionally, several possible lines of inquiry into a field of research often co-exist (see e.g., d'Aspremont 2017, p. 369; Taekema \& van der Burg 2014, p. 130-132). So delineating a legal field of inquiry requires constructing promising lines of inquiry in light of methodological assessments of what constitutes improved understanding. Together, such promising lines of inquiry form a 'problemfield' that requires 'further investigation' (Šešelja \& Straßer 2014, p. 3132).

What represents promising lines of inquiry differs, though, since fields of law and research traditions differ (see e.g., Aagaard 2010; generally Whitt 1990, p. 479). Some fields of law might have a distinct factual context, such as biolaw, which is a field of legal concerns, questions and developments relating to the life sciences, particularly biomedical research such as stem cell research, and developments in applying such knowledge through technology, notably biotechnology. Biolaw's factual context is the life sciences (Chen 2008, p. 1029), primarily biomedical research (Andorno 2013, p. 118; van Beers, Corrias \& Werner 2014, p. 2), and developments regarding applying such knowledge through technology, notably biotechnology. Whether this factual context represents a promising line of inquiry for an individual researcher depends on many factors (see generally Whitt 1990, p. 479). However, the character of the research question is essential (see e.g., Donnelly 2007, p. 83; Van Hoecke 2015, p. 1; Vranken 2011, p. 118). If, for 
instance, the main research question concerns the biolegal concept of humanity, there is potential insight in inquiring what it means to be human and exploring specifically whether we should 'understand "human" to refer to certain biological and genetic characteristics?' (van Beers, Corrias \& Werner 2014, p. 14-15, see also p. 2).

Although assessments of pursuit worthiness greatly depend on the research question, some main lines of inquiry generally tend to pertain to a legal field of inquiry (see generally Whitt 1992). One generally promising line of inquiry concerns the characteristic attributes of the legal framework. The biolegal field provides an example. Biolaw has distinct international dimensions. Biolaw originates partly from international criminal law (van Beers, Corrias \& Werner 2014, p. 9). Presently, a 'return of biolaw to its Nuremberg roots in international criminal law' may be unfolding (van Beers, Corrias \& Werner 2014, p. 14). Another international dimension to biolaw consists of recent international instruments 'heavily influenced by human rights thinking' (van Beers, Corrias \& Werner 2014, p. 10). Central among these instruments is the Convention for the Protection of Human Rights and Dignity of the Human Being with regard to the Application of Biology and Medicine (the Oviedo Convention), April 4, 1997, adopted by the Council of Europe. ${ }^{14}$ Three declarations adopted by the United Nations Educational, Scientific and Cultural Organization (UNESCO) - infused with ideas of human rights are also integral to international biolaw: the Universal Declaration on the Human Genome and Human Rights, November 11, 1997,15 the International Declaration on Human Genetic Data, October 16, $2003^{16}$ and the Universal Declaration on Bioethics and Human Rights, October 19, 2005. ${ }^{17}$ If, for instance, the main research question is whether there is a collective dimension to human dignity (see e.g., Andorno 2013, p. 51; Werner 2014, p. 343), insight can be sought in biolegal regulation (see Werner 2014, p. 347), such as the UNESCO Universal Declaration on Bioethics and Human Rights, which 'conveys the sense of our essential connectedness (and concomitantly, our mutual responsibilities) in a series of articles' (Brownsword 2014, p. 4).

A second example of a generally promising line of inquiry is to discern essential challenges concerning central purposes and values of a legal field. For example, biolegal researchers face biolaw's fundamental challenge of balancing progress and protection. This basic biolegal dilemma can be simplified and summarized in an essential question, at least in biolaw involving biomedical research: How do we balance the freedom of science including the use of biotechnology and concerns

14 Available at conventions.coe.int/treaty/en/Treaties/Html/164.htm (last visited July 4, 2017). Additional protocols omitted.

15 Available at www.unesco.org/new/en/social-and-human-sciences/themes/bioethics/humangenome-and-human-rights/ (last visited July 4, 2017).

16 Available at www.unesco.org/new/en/social-and-human-sciences/themes/bioethics/humangenetic-data/ (last visited July 4, 2017).

17 Available at www.unesco.org/new/en/social-and-human-sciences/themes/bioethics/bioethicsand-human-rights/ (last visited July 4, 2017). 
for human dignity and humanity? (See e.g., van Beers, Corrias \& Werner 2014, p. 2.)

Generally, researchers explore a combination of such aspects and others when forming a promising field of inquiry. Worth emphasizing is that exploring such lines of inquiry continuously requires assessments of pursuit worthiness. Consider the example of balancing progress and protection as an inherent challenge to researching biolaw. Here, the concerns for both progress and protection must be specified. What kind of progress is implied or intended? Acknowledging the inherent complexity of the life sciences and their manifold developmental trajectories is just part of this methodological challenge. Presuppositions about what scientific progress entails interact with ideas of what societal progress means (Altwicker \& Diggelmann 2014). The multitude societal interests, including significant commercial interests, involved when evaluating the prospects of biotechnology for preventing and treating illnesses also generate complexity. In addition to articulating and continuously challenging such ideas regarding what progress entails, the dilemma requires questioning what 'protection' means. Put simply, developments in the life sciences and related technology trigger essential protective concerns, such as concerns about protecting human dignity (Beyleveld \& Brownsword 2001) and humanity (van Beers, Corrias \&Werner 2014). Such concerns involve many questions, as when developments in biotechnology accentuate a societal backdrop of extensive pluralism. Deciding how to understand and relate to this pluralism is integral to conducting biolegal research. Additionally, intergenerational dimensions are of growing concern (see e.g., Andorno 2013, p. 51). Consequently, when aiming for improved understanding of the balancing of progress and protection in the biolegal field, legal researchers confront a noteworthy methodological challenge: they must constantly refine what both progress and protection entail when delineating a pursuit-worthy problem field for further research. Such questioning and specification along promising lines of inquiry depend on assessments of pursuit worthiness.

However, to ensure that efforts at constructing and refining lines of inquiry are transparent (Donnelly 2007, p. 95; Vranken 2011, p. 119) and resonate with the broader research field and community of legal scholars, a researcher cannot assess pursuit worthiness entirely in solitude. Such assessments must be clarified and calibrated through discourse with fellow legal researchers. This aspect of assessing pursuit worthiness is highlighted in the following section.

\section{Clarifying the Potential of Promising Approaches}

When researchers construct promising lines of inquiry, they must take into account that specific lines of inquiry both provide opportunities for insight and entail limitations - as all methodological assessments do (Donnelly 2007, p. 95; Sokhi-Bulley 2013, p. 10; Vranken 2006, p. 93). To clarify which potential for insight a located field of inquiry contains, researchers assess pursuit worthiness 
in discourse with fellow researchers. ${ }^{18}$ Such discourse is both constructive and critical. It is constructive because it allows researchers to develop intellectual distinctiveness by articulating nascent ideas of pursuit worthiness. Also, clarifying pursuit worthiness requires a 'focus on certain positive features' and 'strengths' within an approach (Šešelja \& Straßer 2014, p. 3122). Allowing more than one favoured approach as being promising for further scrutiny is possible (Šešelja \& Straßer 2014, p. 3121; Whitt 1990, p. 476 and p. 478; 1992, p. 632).

Secondly, such discourse is critical because it creates opportunities to revisit presumptions and expectations of fruitfulness, to adjust, supplement or discard them if necessary (Donnelly 2007, p. 79; Šešelja, Kosolosky \& Straßer 2012, p. 14; Šešelja \& Straßer 2014, p. 3122-3123; Whitt 1990, p. 469). Clarifying and calibrating pursuit worthiness always permits a change of perspective, arguably even serendipity (see e.g., van Gestel, Micklitz \& Maduro 2012, p. 23). Evaluating the methodology for proceeding along certain lines of inquiry is integral. Also, debating pursuit worthiness creates an opportunity to manage 'cognitive dissonance' (Balkin 1993, p. 144) triggered by, for example, gaps, tensions or other 'shortcomings' (Šešelja \& Straßer 2014, p. 3122 and p. 3136). Both exposure to disagreement and discourse aimed at seeking common ground enable such in-depth assessments of individual lines of inquiry and enable comparisons of the pursuit worthiness of various lines of inquiry (see generally Šešelja, Kosolosky \& Straßer 2012, p. 15-17).

Constructive and critical discourse about pursuit worthiness is essential to creativity and innovation in legal research. Clarifying potential through discourse is an active, creative process, accelerated by continuous questioning, resilience (Šešelja \& Straßer 2014, p. 3131) and resourcefulness. Metaphorically speaking, debating assessments of what is pursuit worthy creates a 'space to think' (Riles 2016, p. 23) by imagining (Halpin 2009, p. 149) different, yet interrelated, relevant aspects of the field of inquiry, by turning around the image of a field and trying different lines of inquiry. Such exploration of potential insight creates 'breathing room' for a problem (Riles 2016, p. 24), prior to researchers' choice of the best approach to the research question at hand.

Constructive and critical discourse about pursuit worthiness can also challenge hegemonic presuppositions of what is pursuit worthy in legal research. Some lines of inquiry into a problem field may become dominant at the expense of others (see e.g., van Beers, Corrias \& Werner 2014, p. 2-3). Overlooked potential lines of inquiry cause missed opportunities for insight. Especially if 'scholars have the innate urge to view their own angle as universally valid', as Vranken says (2006, p. 93), constructive and critical discourse about pursuit worthiness is instrumental to legal research and methodology. assessments of pursuit worthiness, see p. 3123-3135. See also p. 3115; Šešelja, Kosolosky and Straßer 2012, p. 6 and p. 12-14; Whitt 1992, p. 477. 


\section{Concluding Remarks}

Throughout this article, I have emphasized that bringing assessments of pursuit worthiness to light benefits debate about legal research and methodology. I have highlighted that assessing pursuit worthiness involves constructing and exploring promising lines of inquiry in search of fruitful contributions to improved understanding of law. In addition, I have emphasized that discourse with fellow researchers helps clarify and calibrate the potential of a located field of inquiry. Naturally, the strengths of an approach often appears most clearly after a researcher has finally chosen and thoroughly substantiated what unfolds as the best way to approach and answer the research question (Vranken 2006, p. 93; 2011, p. 117). Therefore, debate about pursuing legal research often gravitates towards the question of what the most fruitful approach is. Still, attentiveness to researchers' assessments of pursuit worthiness benefits current debate about legal research and methodology in several ways. It contributes to precision and nuance in current discussions about what is fruitful, valuable or useful legal research. Attentiveness to how and why assessments of pursuit worthiness are essential in such discussions may facilitate closer interconnections between related discursive strands. Linking such discursive strands may create 'cross-fertilization' (Virgo 2013, p. 98) of ideas and concerns of pursuit worthiness, even though methodological challenges in one field might not be immediately transferable to other fields. In short, increased attention to assessments of pursuit worthiness nurtures both interest in and open-mindedness to the richness of legal phenomena (Taekema \& van der Burg 2014, p. 138. See also generally Šešelja, Kosolosky \& Straßer 2012, p. 15-17; Whitt 1992, p. 632).

As indicated, more research is needed into how legal researchers assess pursuit worthiness. Particularly needed is legal research into whether it is beneficial to develop criteria that can help specify kinds of potential (see generally Whitt 1990, p. 467; 1992), that can indicate sufficient potential (see generally Šešelja \& Straßer 2014, p. 3122) or that may cause caution. Pivotal is also meta-evaluation of such criteria (see generally Šešelja \& Straßer 2014, p. 3137). Important questions also remain regarding how assessments of pursuit worthiness fit into the bigger picture of the interconnected methodological assessments made throughout the legal research process.

Still, highlighting that legal researchers assess which lines of inquiry are pursuit worthy increases awareness of a specific modality (see generally Whitt 1990, p. 467) of legal research. Here, researchers conduct explorative and tentative assessments of what constitutes improved understanding of law. As such, assessing pursuit worthiness differs both from mapping which lines of inquiry are capable of illuminating a research question and from ultimately determining what unfolds as the best way to approach and solve the research question at hand. Increased awareness of these explorative and tentative aspects of how legal researchers assess pursuit worthiness contributes to contemporary discourse about legal methodology. 
Synne Sæther Mæhle

\section{$7 \quad$ Reference List}

\section{Aagaard 2010}

T. S. Aagaard, 'Environmental Law as a Legal Field: An Inquiry in Legal Taxonomy', Cornell Law Review Vol. 95 Issue 2 2010, p. 221-282.

Alexy 2002

R. Alexy, The Argument from Injustice: A Reply to Legal Positivism, Oxford: Oxford University Press 2002.

\section{Altwicker \& Diggelmann 2014}

T. Altwicker \& O. Diggelmann, 'How is Progress Constructed in International Legal Scholarship?', European Journal of International Law Vol. 25 No. 2 2014, p. 425-444.

Amaya 2015

A. Amaya, The Tapestry of Reason: An Inquiry into the Nature of Coherence and its Role in Legal Argument, Oxford: Hart Publishing 2015.

Andorno 2013

R. Andorno, Principles of international biolaw: Seeking common ground at the intersection of bioethics and human rights, Brussels: Bruylant 2013.

\section{Aroney 2013}

N. Aroney, 'Explanatory Power, Theory Formation and Constitutional Interpretation: Some Preliminaries', Australian Journal of Legal Philosophy Vol. 38 2013, p. 1-31.

\section{d'Aspremont 2015}

J. d'Aspremont, Epistemic Forces in International Law: Foundational Doctrines and Techniques of International Legal Argumentation, Cheltenham: Elgar Publishing 2015.

\section{d'Aspremont 2017}

J. d'Aspremont, 'The International Court of Justice and the Irony of System-Design', Journal of International Dispute Settlement Vol. 8 Issue 2 2017, p. 366-387.

\section{Balkin 1993}

J. Balkin, 'Understanding Legal Understanding: The Legal Subject and the Problem of Legal Coherence', Yale Law Journal Vol. 103 Issue 1 1993-1994, p. 105-176.

\section{Beyleveld \& Brownsword 2001}

D. Beyleveld \& R. Brownsword, Human Dignity in Bioethics and Biolaw, Oxford: Oxford University Press 2001.

\section{Brownsword 2014}

R. Brownsword, 'Human dignity from a legal perspective', in: M. Düwell et al. (eds.), The Cambridge Handbook of Human Dignity: Interdisciplinary Perspectives, Cambridge: Cambridge University Press 2014, p. 1-22.

\section{Chen 2008}

J. Chen, 'Biolaw: Cracking the Code', University of Kansas Law Review Vol. 56 Issue 5 2008, p. 1029-1044.

\section{de Been, Taekema \& van Klink 2016}

W. de Been, S. Taekema \& B. van Klink, 'Introduction: Facts, norms and interdisciplinary research', in: S. Taekema, B. van Klink \& W. de Been, Facts and Norms in Law: Interdisciplinary Reflections on Legal Method, Cheltenham: Elgar Publishing 2016, p. 3-22.

\section{Dickson 2013}

J. Dickson, 'Law and Its Theory: a Question of Priorities', in: J. Keown \& R. P. George (eds.), Reason, Morality, and Law: The Philosophy of John Finnis, Oxford: Oxford University Press 2013, p. 361-378. 


\section{Dickson 2017}

J. Dickson, 'Why General Jurisprudence Is Interesting (February 11, 2017)', Oxford Legal Studies Research Paper No. 17/2017. Available at SSRN: ssrn.com/ abstract=2921820 (downloaded April 27, 2017).

Donnelly 2007

B. Donnelly, 'Subjectivity and Law's Fields of Enquiry', Ratio Juris Vol. 20 No. 1 2007, p. 77-96.

Enoch 2015

D. Enoch, 'Is General Jurisprudence Interesting? (May 1, 2015)'. Available at SSRN: ssrn.com/abstract=2601537 or http://dx.doi.org/10.2139/ssrn.2601537

(downloaded April 27, 2017).

Giudice 2015

M. Giudice, Understanding the Nature of Law: A Case for Constructive Conceptual Explanation, Cheltenham: Elgar Publishing 2015.

Halpin 2009

A. Halpin, 'Methodology and the Articulation of Insight: Some Lessons from MacCormick's Institutions of Law', in: Maksymilian Del Mar \& Zenon Bankowski (eds.), Law as Institutional Normative Order, Farnham: Ashgate 2009, p. 145-159.

Holtermann \& Madsen 2015

J. v. H. Holtermann \& M. R. Madsen, 'European New Legal Realism and International Law: How to Make International Law Intelligible', Leiden Journal of International Law Vol. 28 Issue 2 2015, p. 211-230.

Hoyningen-Huene 2013

P. Hoyningen-Huene, Systematicity: The Nature of Science, Oxford: Oxford University Press 2013.

Larsen, Cooper \& Nystuen 2013

K. M. Larsen, C. G. Cooper \& G. Nystuen, 'Introduction by the editors: is there a "principle of humanity" in international humanitarian law?', in: K. M. Larsen, C. G. Cooper \& G. Nystuen (eds.), Searching for a 'Principle of Humanity' in International Humanitarian Law, Cambridge: Cambridge University Press 2013, p. 1-19.

Laudan 1977

L. Laudan, Progress and Its Problems: Towards a Theory of Scientific Growth, Berkeley: University of California Press, 1977.

Peczenik 2009

A. Peczenik, 'Particulars and Universals in Legal Justification', in: Z. Bankowski \& J. MacLean (eds.), The Universal and the Particular in Legal Reasoning, Aldershot: Ashgate 2009, p. 191-201.

Riles 2016

A. Riles, 'Legal Amateurism (October 25, 2016)', Cornell Legal Studies Research Paper No. 16-41, available at SSRN: papers.ssrn.com/sol3/papers.cfm?abstract_id=2859017 (downloaded October 26, 2016).

Šešelja, Kosolosky \& Straßer 2012

D. Šešelja, L. Kosolosky \& C. Straßer, 'The Rationality of Scientific Reasoning in the Context of Pursuit: Drawing Appropriate Distinctions', Philosophica (Gent) 2012, p. 51-82 (hdl.handle.net/1854/LU-2999523).

Šešelja \& Straßer 2014

D. Šešelja \& C. Straßer, 'Epistemic justification in the context of pursuit: a coherentist approach', Synthese Vol. 191 Issue 13 2014, p. 3111-3141.

\section{Siems 2008}

M. M. Siems, 'Legal Originality', Oxford Journal of Legal Studies Vol. 28 No. 1 2009, p. 147-164. 
Synne Sæther Mæhle

\section{Sokhi-Bulley 2013}

B. Sokhi-Bulley, 'Alternative Methodologies: Learning Critique as a Skill', Law and Method February 2013, p. 6-23.

Taekema \& van der Burg 2014

S. Taekema \& W. van der Burg, 'Towards a Fruitful Cooperation between Legal Philosophy, Legal Sociology and Doctrinal Research: How Legal Interactionism May Bridge Unproductive Oppositions', in: R. Nobles \& D. Schiff (eds.), Law, Society and Community: Socio-Legal Essays in Honour of Roger Cotterrell, Farnham: Ashgate 2014, p. 129145.

van Beers, Corrias \& Werner 2014

B. van Beers, L. Corrias \& W. Werner, 'Introduction: probing the boundaries of humanity', in: B. van Beers, L. Corrias \& W. Werner (eds.), Humanity across International Law and Biolaw, Cambridge: Cambridge University Press 2014, p. 1-21.

van Gestel, Micklitz \& Maduro 2012

R. van Gestel, H.-W. Micklitz \& M. Poiares Maduro, 'Methodology in the New Legal World', EUI Working Paper Law 2012-2013.

Van Hoecke 2015

M. Van Hoecke, 'Methodology of Comparative Legal Research', Law and Method December 2015, p. 1-35.

Virgo 2013

G. Virgo, "We Do This in the Criminal Law and That in the Law of Tort": A New Fusion Debate', in: S. GA Pitel, J. W. Neyers \& E. Chamberlain (eds.), Tort Law: Challenging Orthodoxy, Oxford: Hart Publishing 2013, p. 95-118.

Vranken 2006

J. B. M. Vranken, Exploring the Jurist's Frame of Mind: Constraints and Preconceptions in Civil Law Argumentation, Deventer: Kluwer 2006.

\section{Vranken 2011}

J. B. M. Vranken, 'Methodology of Legal Doctrinal Research: A Comment on Westerman', in: M. Van Hoecke (ed.), Methodologies of Legal Research: Which Kind of Method for What Kind of Discipline?, Oxford: Hart Publishing 2011, p. 111-121.

\section{Werner 2014}

M. Werner, 'Individual and collective dignity', in: M. Düwell et al. (eds), The Cambridge Handbook of Human Dignity: Interdisciplinary Perspectives, Cambridge: Cambridge University Press 2014, p. 343-352.

Whitt 1990

L. A. Whitt, 'Theory Pursuit: Between Discovery and Acceptance', PSA: Proceedings of the Biennial Meeting of the Philosophy of Science Association 1990, p. 467-483.

Whitt 1992

L. A. Whitt, 'Indices of Theory Promise', Philosophy of Science, Vol. 59 No. 4 1992, p. 612-634. 